\title{
AKTUALISASI MANAJEMEN PENINGKATAN MUTU BERBASIS MADRASAH
}

\author{
Ismatul Izzah*
}

Abstract: Along with the changing era toward progress, in the era of increasingly free competition like today, educational institutions are required to be able to provide quality education because of poor quality educational institutions over time will be abandoned by society and eliminated by itself The form of efforts to improve the quality of education undertaken by the government is to establish a policy of quality management based on madrasah by delegating authority from the center to the school (madrasah), where the madrasah are given the flexibility and authority to organize and implement up to evaluate the education carried out Title of actualization of quality improvement management based on madrasah. While the formulation of the problem is how the actualization of quality improvement management based on madrasah, what are the supporting and inhibiting factors in actualizing the management of quality improvement based on madrasah. Based on the formulation of the problem, the purpose of this study is to describe the actualization of quality improvement management based on madrasah, and to describe what are the supporting and inhibiting factors in actualizing the management of quality improvement based on madrasah. In data collection methods through observation, interview and documentation, with informants. While to analyze the data using qualitative descriptive technical analysis, that is to describe and interpret the data that have been obtained so that will describe the actual reality in accordance with the existing phenomenon

The result of the research shows that the actualization of management of quality improvement of education can be implemented well, because madrasah is basically the existence of madrasah from, by and for society and it is time for madrasah based quality management is applied in madrasah to improve education quality Actualization of madrasah based quality improvement management as a national policy, firstly do program planning and situation analysis to know the target to be achieved and do SWOT analyst to know how far the readiness of madrasah in order to improve the quality of education After MPMBM planning is completed by giving birth to the program that must be

•Dosen INZAH Genggong Email: ismaizza83@gmail.com 
implemented, the head of the madrasah performs the division of workload by providing a proportional portion to each individual or group. In evaluating the head of the madrasah perform regular evaluations every week and any problems From this it can be understood that the supporting factor in actualizing the management of quality improvement based on Madrasah Madrasah is the compactness and high morale spirit of the existing elements ranging from head of madrasah to employees, and completeness of existing infrastructure.

Keywords: Quality Improvement Management, Madrasah Based Quality of Education 


\section{A. Pendahuluan}

Perkembangan ilmu pengetahuan sangat ditentukan oleh perkembangan dunia pendidikan, dimana dunia pendidikan mempunyai peran yang sangat startegis dalam menentukan arah maju mundurnya kualitas pendidikan. Hal ini bisa di rasakan ketika sebuah lembaga pendidikan dalam menyelenggarakan pendidikan yang benar-benar bagus, maka dapat di lihat kualitasnya. Berbeda dengan lembaga pendidikan yang melaksankan pendidikan hanya dengan sekedarnya maka hasilnyapun biasa-biasa saja.

Pendidikan merupakan kunci kemajuan, semakin baik kualitas pendidikan yang diselenggarakan oleh suatu masyarakat/bangsa, maka akan diikuti dengan semakin baiknya kualitas masyarakat/bangsa tersebut. Pendidikan adalah usaha sadar dan terencana untuk mewujudkan suasana belajar dan proses pembelajaran agar peserta didik secara aktif mengembangkan potensi dirinya untuk memiliki kekuatan spiritual keagamaan, pengendalian diri, kepribadian, kecerdasan, akhlak mulia, serta keterampilan yang diperlukan dirinya, masyarakat, bangsa dan negara ${ }^{1}$.

Pelaksanaan pendidikan pada lembaga-lembaga pendidikan setidaknya mampu mencapai makna dari pendidikan diatas walaupun memang tidak mudah untuk mencapai semua komponen yang tercantum dalam UU Sisdiknas tersebut, akan tetapi baik lembaga formal maupun nonformal setidaknya bisa memberikan kontribusi untuk mewujudkan peserta didik yang mempunyai kualitas yang di harapkan Edward salis dalam bukunya Total Quality Manajemen In Education menyebutkan, kondisi yang menyebabkan rendahnya mutu pendidikan dapat berasal dari berbagai macam sumber, yaitu miskinnya perencanaan kurikulum, ketidak cocokan pengelolaan gedung, lingkungan kerja yang kurang kondusif, ketidaksesuaian sistem dan prosedur (manajemen) tidak cukupnya jam pelajaran, kurangnya sumber daya dan pengembangan staff. Sedangkan syarifuddin (2002), menyebutkan mutu pendidikan kita rendah terletak pada unsur-unsur dari sistem pendidikan kita sendiri, yakni paling tidak pada faktor kurikulum, sumber daya ketenagaan, sarana dan fasilitas, manajemen madrasah, pembiayaan pendidikan dan kepemimpinan merupakan faktor yang perlu dicermati. Disamping itu, faktor eksternal berupa partisipasi politik rendah, ekonomi tidak berpihak terhadap pendidikan, sosial budaya, rendahnya pemanfaatan sains dan tehnologi, juga memperngaruhi mutu pendidikan ${ }^{2}$

Seringkali kita menyalahkan bahwa lulusan atau output yang dihasilkan oleh lembaga pendidikan tidak sesuai dengan kebutuhan masyarakat saat ini,

\footnotetext{
${ }^{1}$ Undang-Undang RI No. 20 Tahun 2003, Tentang Sistem Pendidikan Nasional, Penerbit Citra Umbara, Bandung, 2003, Hal 3

2 Syarifuddin, Manajemen Mutu Terpadu Dalam Pendidikan, Konsep, Strategi, Dan Aplikasi, Grasindo, Jakarta, 2002
} 
terlebih output yang dihasilkan dari madrasah tidak siap untuk memasuki dunia kerja, hal tersebut bukan kesalahan peserta didik atau pendidik yang mengajarkan pengetahuan, karena mereka hanya pelaku dari program yang telah ditetapkan atasan, walaupun sebagian dari mereka yang berhasil tetapi kebanyakan mutu pendidikan didaerah lain jauh tertinggal dari peradaban manusia

Dari berbagai pengamatan dan analisis, sedikitnya ada tiga indikator yang menyebabkan mutu pendidikan tidak mengalami peningkatan secara merata. Faktor pertama, kebijakan dan penyelenggaraan pendidikan nasional menggunakan pendekatan education production function atau input-output analysis yang tidak dilaksanakan secara konsekuen. Pendekatan ini melihat bahwa lembaga pendidikan berfungsi sebagai pusat produksi yang apabila dipenuhi semua input (masukan) yang diperlukan dalam kegiatan produksi tersebut, maka lembaga ini akan menghasilkan output yang dikehendaki. Pendekatan ini menganggap bahwa apabila input pendidikan seperti pelatihan guru, pengadaan buku dan alat pelajaran, dan perbaikan sarana serta prasarana pendidikan lainnya dipenuhi, maka mutu pendidikan (output) secara otomatis akan terjadi. Dalam kenyataan, mutu pendidikan yang diharapkan tidak terjadi. Mengapa? Karena selama ini dalam menerapkan pendekatan education production function terlalu memusatkan pada input pendidikan dan kurang memperhatikan pada proses pendidikan. Padahal, proses pendidikan sangat menentukan output pendidikan.

Faktor kedua, penyelenggaraan pendidikan nasional dilakukan secara birokratik-sentralistik sehingga menempatkan madrasah sebagai penyelenggara pendidikan sangat tergantung pada keputusan birokrasi yang mempunyai jalur yang sangat panjang dan kadang-kadang kebijakan yang dikeluarkan tidak sesuai dengan kondisi sekolah setempat. Sekolah lebih merupakan subordinasi dari birokrasi diatasnya sehingga mereka kehilangan kemandirian, keluwesan, motivasi, kreativitas/inisiatif untuk mengembangkan dan memajukan lembaganya termasuk peningkatan mutu pendidikan sebagai salah satu tujuan pendidikan nasional.

Faktor ketiga, peran serta warga madrasah khususnya guru dan peran serta masyarakat, orangtua siswa pada umumnya, dalam penyelenggaraan pendidikan selama ini sangat minim. Partisipasi guru dalam pengambilan keputusan sering diabaikan, padahal terjadi atau tidaknya perubahan di madrasah sangat tergantung pada guru. Dikenalkan pembaruan apapun jika guru tidak berubah, maka tidak akan terjadi perubahan di madrasah tersebut. Partisipasi masyarakat selama ini pada umumnya sebatas pada dukungan dana, sedang dukungan-dukungan lain seperti pemikiran, moral, dan barang/jasa kurang diperhatikan. Akuntabilitas madrasah terhadap masyarakat juga lemah. Madrasah tidak mempunyai beban untuk mempertanggungjawabkan hasil pelaksanaan 
pendidikan kepada masyarakat, khususnya orangtua siswa, sebagai salah satu unsur utama yang berkepentingan dengan pendidikan (stakeholder). ${ }^{3}$

Sedangkan menurut sallis (2003) dalam buku Manajemen teori, praktek dan riset, menyebutkan sebagian besar rendahnya mutu disebabkan oleh buruknya Manajemen dan kebijakan pendidikan. Warga madrasah hanyalah pelaksana belaka dari kebijakan yang telah ditetapkan atasannya, pendapat sallis ini mendukung pendapat Juram, salah seorang Begawan mutu dunia. Juran berpendapat bahwa masalah mutu $85 \%$ ditentukan oleh manajemennya, sisanya oleh faktor lainnya. ${ }^{4}$

Peningkatan kualitas pendidikan bukanlah tugas yang ringan, karena tidak hanya berkaitan dengan permasalahan teknis, tetapi mencakup berbagai persoalan yang sangat rumit dan kompleks, baik yang menyangkut perencanaan, pendanaan, maupun efisiensi dan efektifitas penyelenggaraan sistem madrasah. Peningkatan kualitas pendidikan juga menuntut manajemen pendidikan yang lebih baik $^{5}$. Lemahnya manajemen pendidikan memberi dampak terhadap efisiensi internal pendidikan dari sejumlah perserta didik yang putus sekolah atau tinggal kelas.

Pendidikan memberikan kontribusi yang sangat besar terhadap kemajuan suatu bangsa, dan merupakan wahana dalam menerjemahkan pesan-pesan kontribusi serta sarana dalam membangun watak bangsa (nation character building). Masyarakat yang cerdas akan memberi nuansa kehidupan yang cerdas pula, dan secara progresif akan membentuk kemandirian.

Dewasa ini, manajemen pendidikan di Indonesia mengenal dua mekanisme pengaturan yaitu sistem sentralisasi dan desentralisasi, dalam sistem sistem sentralisasi segala sesuatu yang berkenaan dengan penyelenggaraan pendidikan diatur secara ketat oleh pemerintah pusat. Sementara desentralisasi, wewenang pengaturan tersebut diserahkan kepada pemerintah daerah. Yang perlu ditegaskan bahwa implikasi desentralisasi manajemen pendidikan adalah kewenangan yang lebih besar diberikan kepada kabupaten dan kota untuk mengolah pendidikan sesuai dengan potensi dan kebutuhan daerahnya

Manajemen peningkatan mutu berbasis madrasah merupakan model Manajemen yang memberikan otonomi lebih besar kepada madrasah, memberikan fleksibilitas/keluwesan-keluwesan kepada madrasah, dan mendorong partisipasi secara langsung warga madrasah (guru, siswa, kepala madrasah, karyawan) dan masyarakat (orang tua siswa, tokoh masyarakat, ilmuwan, pengusaha, dsb.) untuk

\footnotetext{
${ }^{3}$ Artikel pendidikan, konsep dasar MPMBS, www.dikdasmen.depdiknas.go.id, hal 1-2

${ }^{4}$ Husaini Usmsn, M.Pd., M.T, Manajemen Teori, Praktik Dan Riset Pendidikan, Bumi Aksara, Jakarta, 2006, Hal: 496

${ }^{5}$ Mulyasa, Manajemen Berbasis Sekolah, Remaja Rosda Karya, Bandung, 2004, hal: 21
} 
meningkatkan mutu madrasah berdasarkan kebijakan pendidikan nasional serta peraturan perundang-undangan yang berlaku ${ }^{6}$

Ketentuan otonomi daerah yang dilandasi undang-undang no 22 dan 25 tahun 1999, dan direvisi menjadi UU RI no. 32 tahun 2004 dan UU RI tahun 33 tahun 2004, telah membawa perubahan dalam berbagai bidang kehidupan, termasuk penyelenggaraan pendidikan, bila sebelumnya manajemen pendidikan merupakan wewenang pusat, dengan berlakunya undang-undang tersebut, kewenangan tersebut dialihkan kepemerintah kota dan kabupaten. Sehubungan dengan itu, sidi (2000) menyebutkan dalam buku manajemen berbasis sekolah ada empat isu kebijakan penyelenggaraan pendidikan nasional yang perlu dikonstruksi dalam rangka otonomi daerah, berkaitan dengan peningkatan mutu pendidikan, efisiensi pengelolaan pendidikan, serta relevansi pendidikan dan pemerataan pelayaan pendidikan sebagai berikut:

Pertama, upaya peningkatan mutu pendidikan dilakukan dengan menetapkan tujuan dan standart kompetensi pendidikan, yaitu melalui consensus nasional antara pemerintah dengan seluruh lapisan masyarakat. Kedua, peningkatan efisiensi pengelolaan pendidikan mengarah pada penggelolaan pendidikan berbasis madrasah dengan memberi kepercayaan yang lebih luas kepada madrasah untuk mengoptimalkan sumber daya yang tersedia bagi tercapainya tujuan pendidikan yang diharapkan. ketiga, peningkatan relevansi pendidikan mengarah pada pendidikan berbasis masyarakat. Keempat, pemerataan pelayanan pendidikan mengarah pada pendidikan yang berkeadilan. ${ }^{7}$

Pemberian otonomi pendidikan yang luas pada madrasah merupakan kepedulian permerintah terhadap gejala-gejala yang muncul dimasyarakat serta upaya peningkatan mutu pendidikan secara umum. Pemberian otonomi ini menuntut pendekatan manajemen yang lebih kondusif di madrasah agar dapat mengakomodasi seluruh keinginan sekaligus memberdayakan sebagai komponen masyarakat secara efektif guna mendukung kemajuan serta sistem yang ada dimadrasah

Dalam kerangka inilah manajemen peningkatan mutu berbasis madrasah tampil sebagai upaya dalam meningkatkan mutu pendidikan melalui (1). Peningkatan kemandirian, fleksibilitas, partisipasi, keterbukaan, kerjasama, akuntabilitas, sustainabilitas, dan inisiatif madrasah dalam mengelola, memanfaatkan, dan memberdayakan sumberdaya yang tersedia; (2). Meningkatkan kepedulian warga madrasah dan masyarakat dalam penyelenggaraan pendidikan melalui pengambilan keputusan bersama; (3). Meningkatkan tanggungjawab sekolah kepada orangtua, masyarakat, dan

\footnotetext{
${ }^{6}$ Artikel Pendidikan, Op.Cit, hal 3

${ }^{7}$ Mulyasa, Op.Cit, Hal: 6-7
} 
pemerintah tentang mutu sekolahnya; dan (4). Meningkatkan kompetisi yang sehat antar sekolah tentang mutu pendidikan yang akan dicapai.

\section{B. METODE PENELITIAN}

\section{Pendekatan dan Jenis Penelitian}

Penelitian ini menggunakan pendekatan kualitatif. Menurut Bogdan dan Taylor (1972:5) sebagaimana dikutip Moleong mendefinisikan metode kualitatif sebagai prosedur penelitian yang menghasilkan data deskriptif berupa kata-kata tertulis atau lesan dari orang-orang dan perilaku yang diamati. Pendekatan ini diarahkan pada latar dan inividu tersebut secara holistic (utuh). Jadi, dalam hal ini tidak boleh mengisolasikan individu atau organisasi kedalam variable atau hipotesis, tetapi perlu memandangnya sebagai bagian dari suatu keutuhan. Sedangkan menurut Kirk dan Miller (1986:9) mendefinisikan bahwa penelitian kualitatif adalah tradisi tertentu dalam ilmu pengetahuan social yang secara fundamental bergantung pada pengamatan pada manusia dalam kawasannya sendiri dan berhubungan dengan orang-orang tersebut dalam bahasannya dan dalam peristilahannya. ${ }^{8}$

Adapun alasan penelitian ini menggunakan pendekatan kualitatif adalah karena dalam penelitian ini data yang dihasilkan berupa data deskriptif yang diperoleh dari data-data berupa tulisan, kata-kata dan dokumen yang berasal dari sumber atau informan yang diteliti dan dapat dipercaya.

Metode kualitatif digunakan karena beberapa pertimbangan, pertama menyesuaikan metode kualtatif lebih mudah apabila berhadapan dengankenyaataan ganda; kedua, metode ini menyajikan secara langsung hakekat hubungan antara peneliti dan responden; ketiga, metode ini lebih peka dan lebih dapat menyesuaikan diri dengan penajaman pengaruh bersama dan terhadap pola-pola nilai yang dihadapi. ${ }^{9}$

Dalam penelitian kualitatif data yang dikumpulkan berupa kata-kata, gambar. Selain itu semua data yang dikumpulkan kemungkinan menjadi kunci terhadap apa yang sudah diteliti. Dengahn demikian, laporan penelitian akan berisi kutipan-kutipan data untuk memberi gambaran penyajian laporan tersebut. Data tersebut berasal dari naskah wawancara, catatan lapangan, tape recorder, dokumen pribadi, catatan atau memo dan dokumen resmi lainnya ${ }^{10}$. Penelitian kualitatif menghendaki agar pengertian dan hasil interpretasi yang diperoleh dibandingkan dan disepakati oleh manusia yang dijadikan sumber data. 2000, Hal: 3

${ }^{8}$ Lexy J. Moelong, Metodologi Penelitian Kualitatif, Remaja Rosda Karya, Bandung,

${ }^{9}$ Lexy J. Moelong, Ibid, Hal 5

${ }^{10}$ Lexy J. Moelong, Ibid, Hal 6 
Ada beberapa alasan menggunakan metode deskriptif kuantitatif. Salah satu diantaranya adalah bahwa metode ini telah dingukan secara luas dan dapat meliputi lebih banyak segi dibanding dengan metode-metode penyelidikan yang lain. Metode ini banyak memberikan konstribusi terhadap ilmu pengetahuan melalui pemberian informasi keadaan mutakhir, dan dapat membantu kita dalam mengidentifikasi faktor-faktor yang berguna untuk pelaksanaan percobaan. Selanjutnya metode ini dapat digunakan untuk menghasilkan suatu keadaan yang mungkin terdapat dalam situasi tertentu.

Alasan lain mengapa metode ini digunakan secara luas adalah bahwa data yang dikumpulkan dianggap sangat bermanfaat dalam membantu kita untuk menyelesaikan diri, atau dapat memecahkan masalah-masalah yang timbul dalam kehidupan sehari-hari. Metode deskriptif juga membantu kita mengetahui bagaimana caranya mencapai tujuan yang diinginkan, lagi pula penelitian deskriptif lebih banyak digunakan dalam bidang penyelidikan dengan alasan dapat diterapkannya pada berbagai macam masalah.

\section{Kehadiran Peneliti}

Dalam penelitian kualitatif, kehadiran peneliti bertindak sebagai instrumen sekaligus pengumpul data. Kehadiran peneliti mutlak diperlukan, karena disamping peneliti kehadiran peneliti juga sebagai pengumpul data. Sebagaimana salah satu ciri penelitian kualitatif dalam pengumpulan data dilakukan sendiri oleh peneliti. ${ }^{11}$ Sedangkan kehadiran peneliti dalam penelitian ini sebagai pengamat partisipan/ berperanserta, artinya dalam proses pengumpulan data peneliti mengadakan pengamatan dan mendengarkan secara secermat mungkin sampai pada yang sekecil-kecilnya sekalipun. ${ }^{12}$

\section{Sumber Data}

Yang dimaksud sumber data dalam penelitian adalah subjek dari mana data-data diperoleh. Untuk mempermudah mengidentifikasi sumber data penulis mengklasifikasi sumber data menjadi 3 huruf depan P singkatan dari bahasa inggris

$\mathrm{P}=$ person, sumber data berupa orang, dimana sumber data yang bisa memberikan data berupa jawaban lisan melalui wawancara ata jawaban terulis melalui angket

$\mathrm{P}=$ place, sumber data berupa tempat, yaitu sumber data yang menyajikan tampilan berupa keadaan diam dan bergerak, misalnya ruangan, kelengkapan alat, wujud benda, aktivitas, kinerja, kegiatan belajar mengajar dan lain sebagainya

\footnotetext{
2002, hal 11

${ }^{11}$ suharsimi arikunto, prosedur penelitian suatu pendekatan praktek, reneka cipta, jakarta

${ }^{12}$ Lexy J. Moelong, Op.Cit, Hal 117
} 
$\mathrm{P}=$ paper, sumber data berupa simbol, yaitu sumber data yang menyajikan tanda-tanda berupa huruf, angka, gambar, atau simbol-simbol lain, lebih mudahnya bisa disebut dengan metode dokumentasi. ${ }^{13}$

Berkenaan dengan sumber data ini, peneliti menggali data dari penelitian kepustakaan dan penelitian lapangan. Penelitian kepustakaan adalah suatu penelitian yang dilaksanakan melalui studi kepustakaan dengan cara menelaah literatur-literatur yang berkaitan dengan masalah-masalah yang dibahas. Disamping itu, peneliti juga mengambil beberapa buku pedoman, sejarah singkat, prasasti majalah-majalah, dari obyek penelitian dan buku lainnya yang terdapat dalam buku panduan. Sedangkan penelitian lapangan adalah suatu penelitian yang dilaksanakan dengan terjun langsung di lapangan untuk memperoleh data-data yang berkaitan dengan masalah yang dibahas, dalam hal ini peneliti melakukan wawancara dengan kepala madrasah, wakil kepala madrasah urusan kurikulum, wakil kepala madrasah urusan humas. Selain itu juga peneliti melakukan pengamatan/observasi dan analisa dokumen

\section{Prosedur Pengumpulan Data}

Agar diperoleh data yang valid dalam penelitian ini perlu ditentukan teknik-teknik pengumpulan data yang sesuai. Dalam hal ini penulis menggunakan metode:

a. Observasi

Metode observasi adalah suatu metode yang digunakan dengan cara pengamatan dan pencatatan data secara sistematis terhadap fenomena-fenomena yang diselidiki. Sedangkan menurut Suharsimi Arikunto menyebutkan observasi atau disebut pula dengan pengamatan meliputi penglihatan, penciuman, pendengaran, peraba, dan pengecap. ${ }^{14}$

b. Interview/Wawancara

Interview yang sering juga disebut dengan wawancara atau kuesioner lisan, adalah sebuah dialog yang dilakukan oleh pewawancara (interviewer) untuk memperoleh informasi dari terwawancara (interviewer $^{15}$

Dalam penelitian ini, peneliti menggunakan metode interview dalam bentuk interview bebas terpimpin. Menurut suharsimi arikunto, interview bebas terpimpin yaitu melaksanakan interview pewawancara membawa pedoman yang hanya merupakan garis besar tentang hal-hal

\footnotetext{
${ }^{13}$ Suharsimi Arikunto, Loc. Cit, Hal 107

${ }^{14}$ Suharsimi Arikunto, Ibid, Hal: 133

${ }^{15}$ Suharsimi Arikunto, Ibid, hal 132
} 
yang akan ditanyakan dan untuk selanjutnya pertanyaan-pertanyaan tersebut diperdalam ${ }^{16}$

c. Dokumentasi

Dokumentasi, dari asal katanya dokumen, yang artinya barangbarang tertulis. Didalam melaksanakan metode dokumentasi, peneliti menyelidiki benda-benda tertulis seperti buku-buku, majalah, dokumen, peraturan-peraturan, notulen rapat, catatan harian, dan sebagainya. ${ }^{17}$

Dalam metode dokumentasi ini peneliti mengumpulkan data-data yang dimiliki lembaga dan peneliti menformulasikan dan menyususunyan dalam bentuk laporan sesuai dengan kebutuhan yang diperlukan

\section{Analisis Data}

Adapun data yang diperoleh peneliti dalam penelitian ini akan disajikan secara deskriptif kualitatif. Adapun yang dimaksud dengan deskriptif kualitatif menurut Bogon dan Taylor yang dikutip Lexy J. Moelong adalah metode yang digunakan untuk menganalisis data dengan mendeskipsikan data melalui bentuk kata-kata tertulis atau lisan dari orang-orang dan prilaku yang diamati ${ }^{18}$, sehingga dalam penelitian deskriptif kualitatif ini peneliti menggambarkan realitas yang sebenarnya desuai dengan fenomena yang ada secara rinci, tuntas dan detail. Sedangkan dalam analisis data ini, peneliti menggunakan metode:

a. Metode Induktif

Metode induktif adalah pengambilan kesimpulan dimulai dari pernyataan atau fakta-fakta khusus menuju pada kesimpulan yang bersifat umum ${ }^{19}$. Atau bisa didefiniskan dengan berfikir induktif adalah berangkat dari fakta-fakta yang khusus atau perisriwa yang konkrit, kemudian dari fakta-fakta atau peristiwa-peristiwa yang khusus dan konkrit itu ditarik generalisas yang mempunyai sifat umum.

b. Metode Deduktif

Metode deduktif adalah pengambilan kesimpulan dimulai dari pernyataan yatau fakta-fakta yang bersifat umum untuk kemudian ditarik pada persoalan yang bersifat khusus dan spesifik. Atau berfikir induktif adalah berangkat dari fakta-fakta yang khusus, peristiwa-peristiwa yang konkret, kemudian peristiwa yang konkret itu ditarik generalisasigeneralisasi yang bersifat umum. ${ }^{20}$

\footnotetext{
${ }^{16}$ Suharsimi Arikunto, Ibid, hal 132

${ }^{17}$ Suharsimi Arikunto, Ibid, hal 135

${ }^{18}$ Lexy Moelong, Metodologi Penelitian Kualitatif, Bandung, Remaja Rosda Karya 2003,

${ }^{19}$ Nana Sujdana, Tuntunan Penyusunan Karya Ilmiah, Sinar Baru Bandung, 1998. Hal 7

${ }^{20}$ Nana Sujdana, Ibid, Hal 6
} hal 3 
c. Metode komparasi

Meteode komparasi yaitu metode yang dilakukan dengan mengabungkan antara fakta-fakta yang ada dengan berdasarkan pada teori yang ada guna untuk melengkapi penjelasan yang diperlukan

\section{Pengecekan Keabsahan Temuan}

Setelah data terkumpul dan sebelum peneliti menulis laporan hasil penelitian, maka peneliti mengecek kembali data-data yang telah diperoleh dengan mengkroscek data yang telah didapat dari hasil interview dan mengamati serta melihat dokumen yang ada, dengan ini data yang didapat dari peneliti dapat diuji keabsahanya dan dapat dipertanggungjawabkan.

Selain itu peneliti juga menggunakan tehnik observasi mendalam dan tri anggulasi sumber data, yakni dengan pemeriksaan teknik pemeriksaan keabsahan data yang memanfaatkan sesuatu yang lain diluar data itu untuk keprluan pengecekan atau sebagai pembanding terhadap data itu. ${ }^{21}$ Dan juga dengan metode preer deriefing, yaitu dengan mendiskusikan data yang telah terkumpul dengan pihak-pihak yang memiliki pengetahuan dan keahlian yang relevan, baik teman sejawat (Agus Zainul Fitri, S.Pd.I, Nurul Huda, M.karim dan Didik Sugiarto) dan lebih-lebih dosen pembimbing peneliti.

${ }^{21}$ Lexy Moelong, Loc.Cit, hal 178 


\section{Pembahasan}

Peningkatan mutu dan kualitas pendidikan bukanlah tugas yang ringan, karena tidak hanya berkaitan dengan pelaksanaan teknis, tetapi mencakup berbagai persoalan yang sangat kompleks. Lemahnya manajemen pendidikan memberi dampak terhadap efisiensi internal pendidikan, ini dapat dilihat dari sejumlah peserta didik yang putus sekolah, tinggal kelas atau harus mengulang dalam ujian nasional.

Manajemen peningkatan mutu berbasis madrasah akan memperkuat rujukan prefensi nilai yang dianggap strategis dalam arti sesuai dengan kebutuhan masyarakat dan kebutuhan anak untuk dapat hidup dan berinteraksi dimasyarakatnya. Setiap peserta didik dan masyarakat memiliki sistem nilai yang menjadi rujukan baik pribadi maupun lembaga. Nilai-nilai itu akan menjadi kekuatan motivasional bagi prilaku individu ataupun masyarakat, serta menjadi kekuatan yang mengintegrasikan kepribadian masyarakat dan kebudayaan. Dengan demikian manajemen peningkatan mutu berbasis madrasah akan memperkuat kapasitas madrasah untuk meningkatkan relevansi program pendidikannya sesuai dengan kebutuhan daerah.

Manajemen peningkatan mutu berbasis madrasah sebagai salah satu kebijakan pemerintah yang memberikan kewenangan lebih kepada madrasah untuk merencanakan, mengelola, melaksanakan, sampai pada evaluasi dengan situasi madrasah sesuai dengan apa yang diharapkan. Manajemen peningkatan mutu berbasis madrasah dilaksanakan dengan beberapa alasan yaitu:

1. Dengan pemberian otonom yang lebih besar kepada madrasah maka madrasah akan lebih aktif dan kreatif dalam meningkatkan mutu madrasah

2. Dengan pemberian fleksibelitas atau keluwesan-keluwesan yang lebih besar kepada madrasah untuk mengelola sumber dayanya, madrasah akan lebih luwes dan lincah dalam mengadakan dan memanfaatkan sumber daya madrasah secara optimal untuk meningkatkan mutu madrasah

3. Madrasah lebih mengatahui kekuatan, kelemahan, peluang dan ancaman bagi dirinya sehingga ia dapat mengoptimalkan pemanfaatan sumber daya yang tersedia untuk memajukan madrasahnya

4. Madrasah lebih mengetahui lembaganya, khususnya input pendidikan dan didayagunakan dalam proses pendidikan sesuai dengan perkembangan dan kebutuhan peserta didik

5. Pengambilan keputusan yang dilakukan oleh madrasah lebih cocok untuk memenuhi kebutuhan madrasah, karena pihak madrasah yang paling tahu apa yang terbaik bagi dirinya

6. Penggunaan sumber daya pendidikan lebih efisien dan efektif bila mana dikontrol oleh masyarakat setempat 
7. Keterlibatan semua warga madrasah dan masyarakat dalam pengambilan keputusan madrasah menciptakan transparasi dan demokrasi yang sehat

8. Madrasah dapat bertanggung jawab tentang mutu pendidikan kepada masing-masing pemerintah, orang tua peserta didik dan masyarakat pada umumnya, sehingga dia akan berupaya semaksimal mungkin untuk melaksankan dan mencapai mutu pendidikan yang lebih direncanakan

9. Madrasah dapat melakukan persaingan yang sehat untuk meningkatkan mutu melalui upaya inovatif dengan madrasah-madrasah lain untuk meningkatkan mutu pendidikan melalui upaya inovatif dengan dukungan orang tua peserta didik, masyarakat dan pemerintah daerah setempat dan

10. Madrasah dapat secara cepat merespon aspirasi masyakat dan lingkungan yang berubah dengan cepat ${ }^{22}$

Pelaksanaan manajemen peningkatan mutu berbasis madrasah di madrasah setidaknya memperhatikan tahapan-tahapan sebelum menetapkan program dan kegiatan, dimana hal ini dilakukan untuk mengetahui kekuatan dan kelemahan yang akan dihadapi madrasah, yang tentunya didasarkan pada visi dan misi madrsah, karena program yang dilaksanakan pada esensinya penjabaran dari visi dan misi madrasah

Dalam upaya peningkatan mutu pendidikan membuat program yang sebelumnya telah dianalisis dan dilokakaryakan bersama dengan para guru, staff dan kepala bagian, hal ini dilakukan agar semua elmen yang ada dimadrasah guna mengetahui dan ikut berperan serta dalam pelaksanaan program, sebelum program dilokakaryakan kepala madrasah sebagai pimpinan memberikan rancangan program yang akan dilokakaryakan dan ditetapkan menjadi program madrasah untuk dilaksanakan

Program yang dirancang tadi kemudian dilokakaryakan dan dianalisis untuk mengetahui peluang dan hambatan yang akan dihadapi, kemudian ditetapkan dalam program dan direalisasikan dalam bentuk kegiatan. Dalam pelakasanaan program yang sudah ada kemudian diberikan kepada bagian yang melingkupinya, baik yang sifatnya internal maupun yang eksternal dengan dasar disesuaikan dengan job dan wewenang dari program tersebut.

Berdasarkan analisis tersebut kemudian mengidentifikasikan kebutuhan madrasah dan merumuskan visi, misi, dan tujuan dalam rangka menyajikan pendidikan yang berkualitas bagi siswanya sesuai dengan konsep pendidikan nasional yang akan dicapai. Hal penting yang perlu diperhatikan sehubungan dengan identifikasi kebutuhan dan perumusan visi, misi, strategi dan tujuan adalah keterlibatan semua warga yang ada di madrasah dan juga perwakilan dari orang tua siswa dan juga dari dari Depag, guna untuk lebih mempermudah didalam hal 33-34

${ }^{22}$ Ade Irawan Dkk, Mendagangkan Sekolah, Indonesia Coruption Watch, Jakarta, 2004, 
perumusan visi, misi, strategi, tujuan serta program madrasah, yang nantinya akan mempermudah dalam pelaksanaan visi, misi, strategi dan tujuan madrasah yang akan dicapai, karena pada esensinya aktualisasi manajemen peningkatan mutu berbasis madrasah ini adalah otonomi madrasah + fleksibelitas + partisipasi masyarakat untuk mencapai sasaran mutu madrasah

Dalam proses pelaksanaan program yang telah dibuat, tentunya perlu dilakukan monitoring dan evaluasi program, hal ini untuk mengetahui apakah program yang telah dibuat benar-benar dapat dilaksanakan dengan benar atau hanya sekedar terlaksana saja, karena salah satu ciri-ciri dari pendidikan yang bermutu adalah adanya evaluasi yang konsekwen, dan dilakukan secara intensif dan terus menerus

Proses monitoring dan evaluasi ini disamping sebagai sebuah penilaian program, juga dapat membuat strategi baru dalam pelaksanaan program yang telah ada, karena dalam monitoring dan evaluasi ini juga melibatkan berbagai unsur dan elmen yang ada baik dari Depag, komite madrasah lebih-lebih staff dan elmen yang ada dimadrasah. Hal inilah yang merupakan salah satu ciri manajemen peningkatan mutu berbasis madrsah ini diterapkan, karenanya madrasah tidak lagi harus sama persis dengan juklak dan juklis yang dibuat oleh pusat akan tetapi madrasah bisa berkreasi dan berimprovisasi sesuai dengan kondisi dan keinginan warga madrasah yang dikehendaki

Selain diatas juga perlu diperhatikan didalam pengaktualisasikan manajemen peningkatan mutu berbasis madrasah, yaitu;

1. Sumber daya; yang meliputi sumber daya manusia yang meliputi guru, karyawan, siswa dan sumber daya alam dimana madrasah mempunyai fleksibilitas dalam mengatur semua sumber daya sesuai dengan kebutuhan setempat. Sumber daya ini mempunyai pengaruh yang cukup besar dalam menentukan baik buruknya mutu pendidikan, karenanya madrasah dengan menerapkan manajemen peningkatan mutu berbasis madrasah ini diberi keleluasaan dan hak otonom untuk mengatur dan mengelola sumber daya madrasah guna untuk meningkatkan mutu pendidikan. Begitu juga dengan pemanfatan fasilitas dan pengadaan sarana prasarana, madrasah harus menyediakan fasilitas dan sarana prasarana yang memadai untuk meningkatkan mutu pendidikan, karena akan sangat ironis ketika sumber daya manusia memadai akan tetapi sarana prasaran dan fasilitas kurang mendukung dapat meningkatkan mutu pendidikan begitu juga sebaliknya

2. Kurikulum; berdasarkan kurikulum standar yang telah ditentukan secara nasional, madrasah bertanggung jawab untuk mengembangkan kurikulum baik dari standar materi (content) maupun proses penyampaiannya, madrasah harus menciptakan suasana belajar yang menyenangkan dan melibatkan semua indera dan lapisan otak (kognitif, afektif dan 
psikomotorik), serta menciptakan tantangan agar siswa tumbuh dan berkembang secara intelektual dengan menguasai ilmu pengetahuan, terampil, memilliki sikap arif dan bijaksana, karakter dan memiliki kematangan intelektual, spiritual dan emosional

3. Personil madrasah; madrasah bertanggung jawab dan terlibat dalam proses rekrutmen (dalam arti penentuan jenis guru yang diperlukan) dan pembinaan struktural staf madrasah (kepala madrasah, wakil kepala madrasah, guru dan staf lainnya). Sementara itu pembinaan profesional dalam rangka pembangunan kapasitas/kemampuan kepala madrasah dan pembinaan keterampilan guru dalam pengimplementasian kurikulum termasuk staf kependidikan lainnya dilakukan secara terus menerus atas inisiatif madrasah. Dalam konteks ini pengembangan profesioanl harus menunjang peningkatan mutu dan penghargaan terhadap prestasi perlu dikembangkan.

4. Pertanggung-jawaban (accountability); madrasah dituntut untuk memilki akuntabilitas baik kepada masyarakat maupun pemerintah. Hal ini merupakan perpaduan antara komitment terhadap standar keberhasilan dan harapan/tuntutan orang tua/masyarakat. Pertanggung jawaban (accountability) ini bertujuan untuk meyakinkan bahwa dana masyarakat dipergunakan sesuai dengan kebijakan yang telah ditentukan dalam rangka meningkatkan kualitas pendidikan. Untuk itu setiap madrasah harus memberikan laporan pertanggung-jawaban dan mengkomunikasikannya kepada orang tua/masyarakat dan pemerintah, dan mengkakaji ulang secara komprehensif terhadap pelaksanaan program madrasah dalam proses peningkatan mutu.

Madrasah sebagai lembaga pendidikan yang melaksanakan manjemen peningkatan mutu berbasis madarasah banyak hal yang menjadi pendukung, baik dari segi sumber daya madrasah ataupun yang lain.

Pada pelaksanaan program yang telah dibuat tidak menutup kemungkinan ada faktor penghambat, karenanya untuk meminimalisir dan bahkan mengantisipasi faktor penghambat maka dilakukan monitoring dan evaluasi untuk mengetahui apakah program yang telah direncanakan dapat dilaksanakan sesuai dengan tujuan, dan sejauh mana pencapaiannya. Karena fokusnya adalah mutu siswa, maka kegiatan monitoring dan evaluasi harus memenuhi kebutuhan untuk mengetahui proses dan hasil belajar siswa. Secara keseluruhan tujuan dan kegiatan monitoring dan evaluasi ini adalah untuk meneliti efektifitas dan efisiensi dari program dan kebijakan yang terkait dalam rangka peningkatan mutu pendidikan.

Untuk pengenalan dan menyamakan persepsi sekaligus untuk memperoleh masukan dalam rangka perbaikan, maka sosialisasi harus terus dilakukan. Kegiatan-kegiatan yang bersifat uji coba harus dilakukan untuk mengetahui kendala-kendala yang mungkin muncul didalam pelaksanaannya untuk kemudian 
dicari solusinya dalam rangka mengantisipasi kemungkinan-kemungkian kendala yang muncul di masa mendatang dengan haparan peningkatan mutu pendidikan akan dapat diraih sebagai pelaksanaan dari proses pengembangan sumber daya manusia menghadapi persaingan global yang semakin ketat dan tidak mementu

\section{Kesimpulan}

Aktualisasi manajemen peningkatan mutu berbasis madrasah terbagi dalam beberapa langkah:

1. Perencanaan, dimana dalam perencanaan ini dimuali dengan pembacaan secara umum untuk menentukan program yang akan dibuat yang meliputi analisis situasi untuk mencapai sasaran yang dituju, kemudian merumuskan sasaran yang tercermin dalam visi dan misi dan baru kemudian melakukan analisis SWOT untuk mengetahui kekuatan, kelemahan, peluang dan tantangan yang akan dihadapi. Setelah perencanaan terselesaikan dengan melahirkan beberapa program, kepala madrasah melakukan pembagian beban kerja dengan memberikan porsi yang proposional kepada setiap individu maupun kelompok untuk melaksanakan program-program yang telah dibuat.

2. Sedangkan dalam pelaksanaan peningkatan mutu pendidikan, Madrasah membuat program-program sesuai dengan job dan wewenang masingmasing bagian, mulai dari kepala madrasah sampai karyawan ikut berperan secara aktif dalam melaksanakan program yang telah dibuat yang tentunya yang berorientasi pada peningkatan mutu pendidikan

3. Dalam Pengawasan mutu pendidikan dari program-program yang telah dibuat dan laksanakan dan untuk mengetahui tingkat keberhasilan maka dilakukan evaluasi, dalam pelaksanaan evaluasi ini dilakukan secara rutin yakni setiap hari senin dan berkala serta setiap ada masalah

Faktor Pendukung Dan Penghambat Dalam Mengaktualisasikan Menajemen Peningkatan Mutu Pendidikan

\section{Faktor Pendukung}

Dukungan dari berbagai elmen yang ada dimadrasah, guru, staff, kepala baigian dan orang tua siswa

Sarana dan prasarana (perpustakaan, lab.komputer, lab.fisika, lab.kimia, lab.bahasa, dsb) yang memadai

Kebijakan yang dikeluarkan oleh madrasah dapat dilaksanakan sesuai dengan target dan sasaran

2. Faktor Penghambat 
Guru (Tenaga pengajar 75\% perempuan) kadang juga sering izin tidak masuk mengajar, hal ini menghambat program-program yang telah direncakan dari madrasah

Sebagian guru kurang bisa menggunakan fasilitas yang ada dalam proses belajar mengajar, seperti penggunaan audio visual dan media pembelajaran yang lain 


\section{Daftar Pustaka}

Ade Irawan Dkk, Mendagangkan Sekolah, Indonesia Coruption Watch, Jakarta, 2004, hal 33-34

Al-Qur'an Dan Terjemahanya, Mujamma' Al-Malik Fadh Li Thiba'at Mushaf Asy-Syarif Medinah Muanawwaroh Po.Box 6262 Kerajaan Saudi Arabiya, Tahun 1420.

Arcaro, Jerome S. 2005. Pendidikan Berbasis Mutu, Prinsip-Prinsip Dan Tata Langkah Penerapan, Yogyakarta : Pustaka Pelajar.

Arikunto. Suharsimi, 2002. Prosedur Penelitian Suatu Pendekatan Praktek, Jakarta: Rineka Cipta.

Artikel Bulletin Pengawasan No 13\&14 Tahun 1998, http//: www.google.co.id

Bukori. Muhammad Dkk, 2005. Azas-Azas Manajemen. Yogyakarta: Aditya Media.

Fattah. Nanang, 2004. Landasan Manajemen Pendidikan, Bandung: PT Remaja Rosda Karya.

Hasibuan, Malayu S.P. 1990. Manajemen Dasar, Pengetian, Dan Masalah. Jakarta: CV. Haji Mas Agung.

http//: www.man3malang.com

Kamisa. 1997. Kamus Lengkap Bahasa Indonesia, Surabaya: Penerbit Kartika.

Moelong. J Lexy, 2003. Metodologi Penelitian Kualitatif, Bandung: Remaja Rosda Karya

Mulyasa, E. 2004. Manajemen Berbasis Sekolah; Konsep, Strategi Dan Implimentasi, Bandung: Remaja Rosda Karya.

2005. Menjadi Kepala Sekolah Profesional, Bandung: PT. Remajda Rosda Karya.

Pidarta. Made, 2002. Jakarta . Manajemen Pendidikan Indonesia, Rineka Cipta.

Rusmianto, Kepemimpinan Kepala Sekolah Berwawasan Visioner-Transformatif Dalam Otonomi Pendidikan, Jurnal El-Herakah, UIIS-Malang, Edisi 59, Tahun XXIII, Maret-Juni 2003 
Sujdana. Nana, 1998. Tuntunan Penyusunan Karya Ilmiah, Bandung: Sinar Baru.

Syarifuddin, 2002, Manajemen Mutu Terpadu Dalam Pendidikan, Konsep, Strategi, Dan Aplikasi. Jakarta: PT. Gramedia Widia Sarana Indonesia.

Undang-Undang RI No. 20 Tahun 2003, Tentang Sistem Pendidikan Nasional, Bandung: Penerbit Citra Umbara.

Usman. Husaini, 2006. Manajemen Teori, Praktik Dan Riset Pendidikan. Jakarta: Bumi Aksara.

www.dikdasmen.depdiknas.go.id, Artikel pendidikan, Konsep Dasar Manajemen Peningkatan Mutu Berbasis Sekolah. 